\title{
Primary Xanthoma of the Mandible: Report of a Rare Case
}

\author{
Dominic Morel $^{1}$ - Robert D. Kelsch ${ }^{2,3} \cdot$ Patrick J. Nolan $^{1,4}$
}

Received: 2 June 2015/Accepted: 30 July 2015/Published online: 8 August 2015

(C) Springer Science+Business Media New York 2015

\begin{abstract}
Xanthoma is a lesion most commonly seen in soft tissues such as the skin, subcutis, or tendon sheaths. Xanthoma formation is often associated with primary or secondary hyperlipidemia. Primary bone xanthomas are extremely rare benign bone lesions not associated with hyperlipidemia, histopathologically characterized by histiocytes, abundant lipid containing macrophages (foam cells), and multinucleated giant cells. Cholesterol clefts can be found in the medullary bone. Less than ten cases of xanthoma in the mandible have been reported. We present a rare primary intrabony xanthoma in a normolipidemic patient.
\end{abstract}

Keywords Xanthoma - Intraosseous xanthoma .

Mandible · Foamy histiocytes · Non-Langerhans histiocytic process

Patrick J. Nolan

pnolan@montefiore.org

1 Division of Oral and Maxillofacial Surgery, Department of Dentistry, Montefiore Medical Center, 111 E. 210th Street, Bronx, NY 10467-2490, USA

2 Departments of Dental Medicine and Pathology and Laboratory Medicine, NSLIJ Health System, New Hyde Park, NY, USA

3 Departments of Dentistry and Pathology, Montefiore Medical Center/Albert Einstein College of Medicine, Bronx, NY, USA

4 Albert Einstein College of Medicine, Bronx, NY, USA

\section{Introduction}

Xanthomas are benign lesions of soft tissue commonly seen in skin or over subcutaneous tissue of tendon sheaths and extensor surfaces after minor trauma or friction [1, 2]. Xanthoma formation occurs most frequently in patients with endocrine and metabolic diseases [1-4]. Xanthoma is derived from the Greek xanthós, which means yellow, and is related to the altered metabolism of lipids and the accumulation of yellow pigment in skin and other internal organs [3]. Histiocytic diseases have been divided into Langerhans cell related histiocytic disease (LCH) and nonLangerhans histiocytic processes. The xanthoma is a nonLangerhans histiocytic process and is characterized microscopically by lipid-containing macrophages, or foam cells [4].

The primary xanthoma of bone is extremely rare, and when present is often secondary to hyperlipidemia type II or III or diabetes mellitus [5, 6]. When systemic metabolic disease and lipid disease are ruled out, the bony lesion is termed primary xanthoma of bone [3-5].

\section{Case Report}

A 40 year old African American female presented to the Montefiore Medical Center Oral and Maxillofacial Surgery clinic for evaluation of pain in the left mandibular quadrant of stated 1 day duration. She reported no significant past medical or surgical history and denied previous local trauma. On examination, there was mild lateral and inferior expansion of the left face in the area of the mandibular body. No facial paresthesia or paralysis was present. On intraoral examination, the patient exhibited a full complement of teeth without caries or previous dental restorations. 
The oral mucosa was within normal limits. Mild buccal expansion of the left mandibular body was noted. All teeth were vital and without percussion sensitivity. A panoramic radiograph taken at the time of presentation indicated left hemi-mandibular enlargement with a "honeycomb-type" multilocular, mixed radiolucent-radiopaque appearance extending from the sigmoid notch to the mandibular midline (Fig. 1). The larger size of teeth on the left side suggests patient positioning error, which gives the impression of a larger, more expansile lesion than is seen in the cone beam computed tomography (CBCT). The mandibular canal was well demarcated and not significantly displaced. The CBCT confirmed the buccal cortex and inferior border expansion and highlighted an ill-defined mottled process with a generalized opacification of the marrow space (Fig. 2).

An open bone biopsy was performed via intraoral approach under intravenous sedation. Access was made into the marrow space by removing a $3.0 \mathrm{~cm} \times 2.0 \mathrm{~cm}$ buccal cortical plate widow using high speed handpiece and chisel. Tissue specimen was collected using bone curette and bone gauge. Yellow "granules" were clinically noted in the cancellous bone. The inferior alveolar nerve was not encountered. Oral amoxicillin and chlorhexidine $0.12 \%$ mouthwash were prescribed.

The buccal cortical plate and specimen were submitted in $10 \%$ formalin for histologic examination. Histologic examination showed a benign proliferative process composed of histiocytic cells involving and infiltrating trabecular bone in a background of loose fibrous connective tissue devoid of any other significant inflammatory infiltrate (Fig. 3). High-power examination demonstrated an abundance of foam cells (Fig. 4). Immunohistochemical staining for CD68 was strongly positive (Fig. 5). Additional immunohistochemical stains for S-100 and CD1a were negative, effectively eliminating Langerhans histiocytic processes. These findings were consistent with xanthoma. Based on the diagnosis, the patient was referred to her primary care physician for hyperlipidemia work-up.

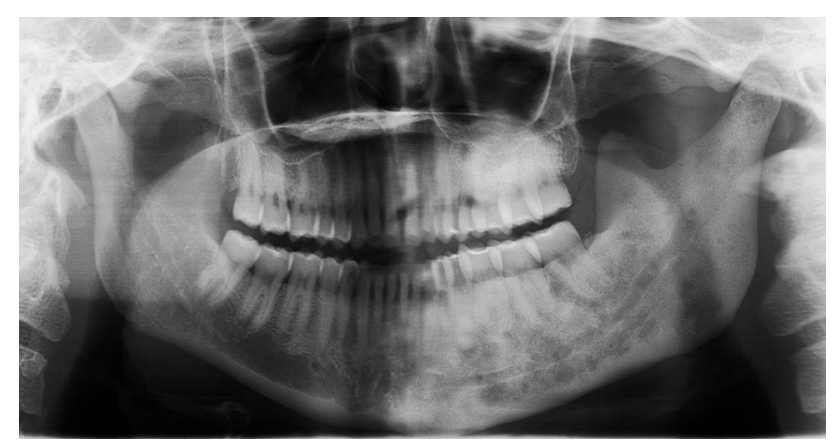

Fig. 1 Panoramic radiograph on presentation. Note the positioning error, depicted by larger teeth on the left side
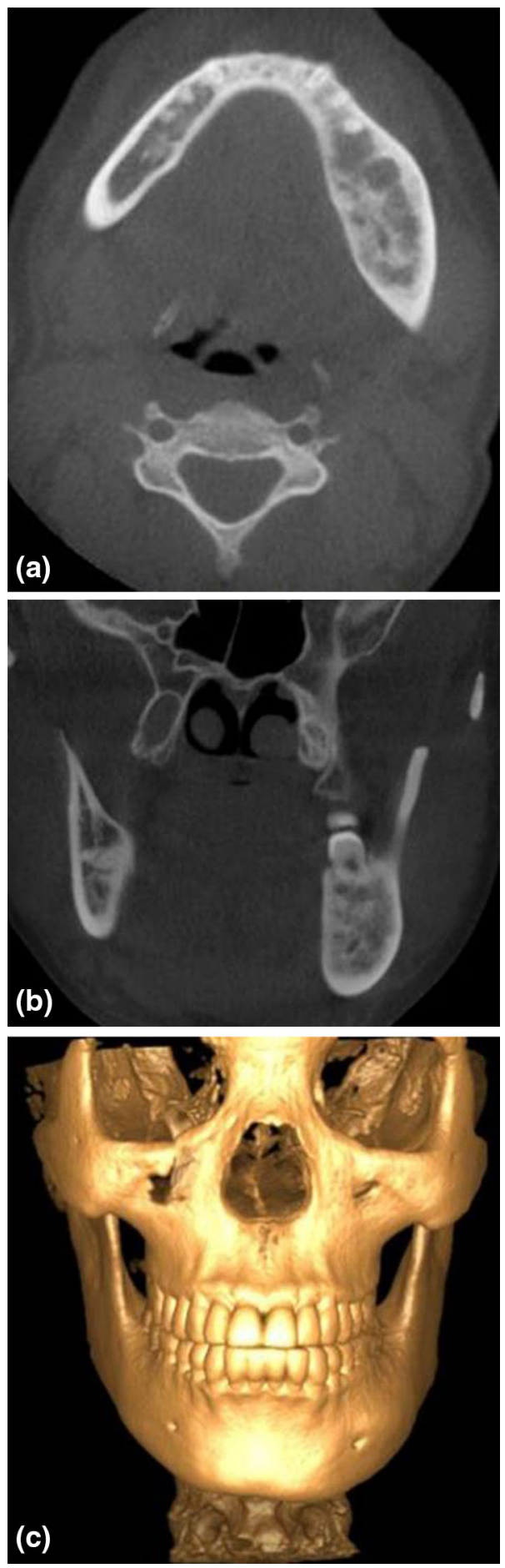

Fig. 2 CBCT on presentation. Axial (a), coronal (b), and 3D reconstruction (c) views

Full lipid profile, amylase, and hemoglobin A1C were within normal limits. Physical exam revealed no other xanthomatous lesions of the skin.

The biopsy site healed well without complication. The mandibular buccal asymmetry improved after the biopsy. 


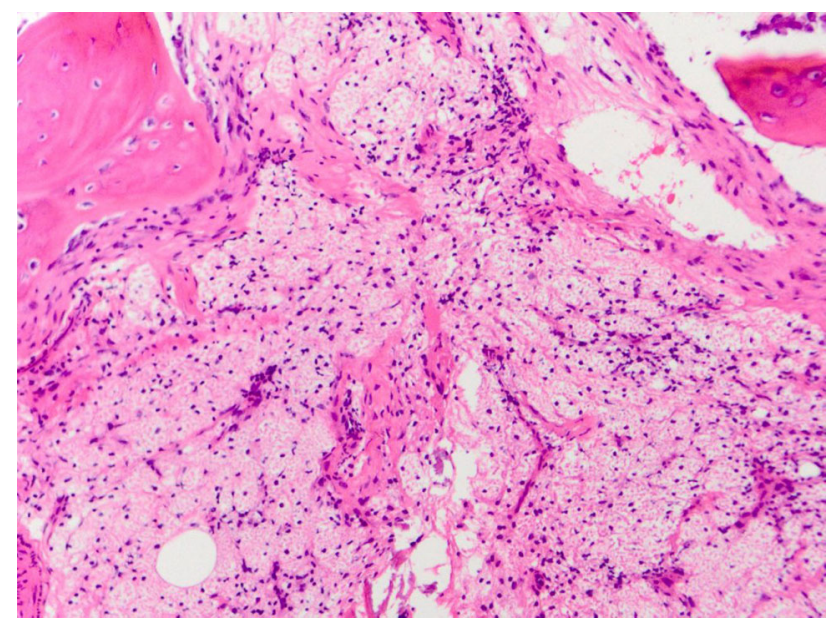

Fig. 3 Photomicrographs. Low power $(\times 10) \mathrm{H}+\mathrm{E}$ stain showing histiocytic cells involving and infiltrating trabecular bone in a background of loose fibrous connective tissue devoid of significant inflammatory infiltrate

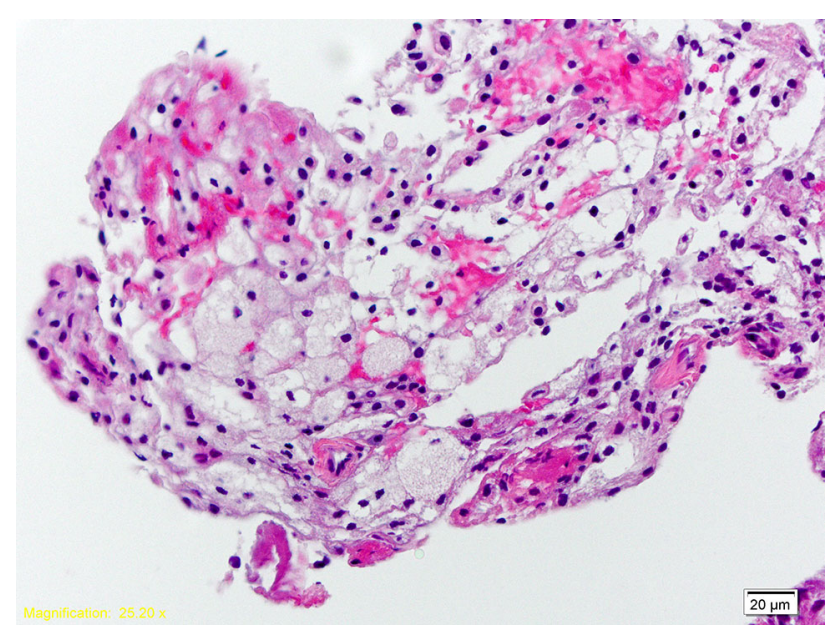

Fig. 4 High magnification $(\times 40) \mathrm{H}+\mathrm{E}$ stain demonstrating the abundance of foamy histiocytes

No further treatment was rendered. A panoramic radiograph was taken at 6 months post-biopsy showing no increase in size (Fig. 6). The patient will be followed every 6 months.

\section{Discussion}

The medical literature is replete with records of xanthomatous lesions of the skin and tendons, usually associated with hyperlipidemia type II and III and lipid storage or metabolism disorders [1]. Primary intraosseous xanthoma of the gnathic bones is rare, especially an intra-bony lesion containing lipid-laden macrophages in patients without lipid disorders [7].

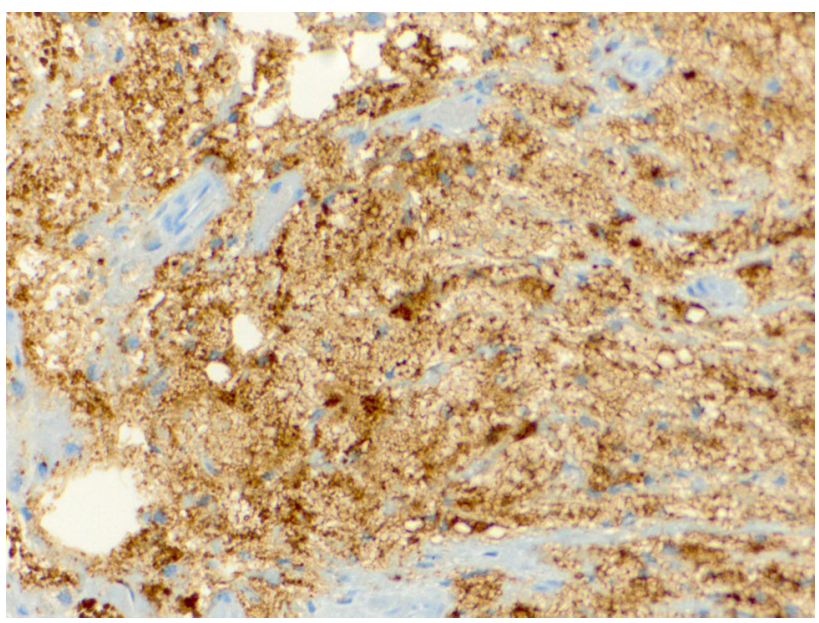

Fig. 5 Xanthoma cells exhibiting strong positive CD68 staining

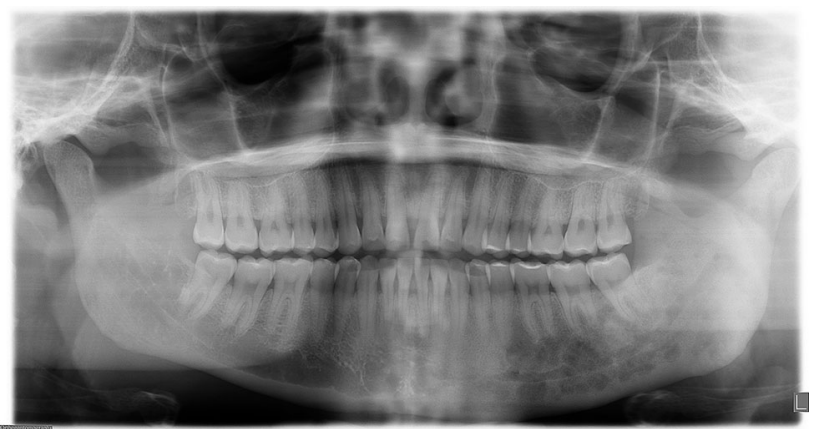

Fig. 6 Panoramic radiograph at 6 month follow-up

The intraosseous xanthoma has been reported to occur at any age, but is infrequent in the pediatric population. Most documented cases were seen between the third and fifth decades [3, 5, 8]. Male are affected twice as much as females $[1,3]$. The lesion is almost always solitary and occurs most frequently in the hand and flat bones [7, 9-11]. In the English language literature, seventeen cases have been reported affecting the temporal bone [2]. Xanthomas of the gnathic bones are hard to quantify as some reports describe xanthomatous lesions without a clear histologic description; however it appears that less than ten cases of primary intraosseous xanthoma of the mandible are reported $[3-5,8,12]$. Although pain is present in up to $60 \%$ of non-gnathic bony xanthomas, pain is an infrequent finding in reported mandibular xanthomas $[4,7]$.

Xanthomas of the craniofacial bones average only a few centimeters in size. In the mandible, reported xanthomas range from 1 to $4 \mathrm{~cm}[3,5,8,12]$, although the lesion in the present case was more significant and extended from the sigmoid notch to the mandibular midline. The radiographic appearance may range from a small, well-demarcated radiolucent lesion with sclerotic margins to diffuse 
Table 1 Clinical, radiological, and histological findings of differential diagnosis of primary xanthoma of the mandible

\begin{tabular}{|c|c|c|c|c|c|c|}
\hline Lesion & Clinical features & Radiographic features & $\begin{array}{l}\text { Histopathologic } \\
\text { features }\end{array}$ & $\begin{array}{l}\text { Positive } \\
\text { markers }\end{array}$ & Treatment & Prognosis \\
\hline $\begin{array}{c}\text { Intraosseous } \\
\text { xanthoma }\end{array}$ & $\begin{array}{l}\text { Age: } 3 \text { rd-5th } \\
\text { decades } \\
\text { Male:female } 2: 1 \\
\text { Site: mandible } \\
\text { Behavior: usually } \\
\text { painless, progress } \\
\text { slowly, may cause } \\
\text { expansion, teeth } \\
\text { vital }\end{array}$ & $\begin{array}{l}\text { Small, well- } \\
\text { demarcated } \\
\text { radiolucent lesion } \\
\text { with sclerotic } \\
\text { margins to diffuse } \\
\text { appearance with } \\
\text { small ill-defined } \\
\text { radiolucencies and } \\
\text { areas of increased } \\
\text { density }\end{array}$ & $\begin{array}{l}\text { Foam cells with faint } \\
\text { granular cytoplasm } \\
\text { and small central } \\
\text { and round nuclei, } \\
\text { fibrous connective } \\
\text { tissue }\end{array}$ & CD68 & Curettage & $\begin{array}{l}\text { Rare } \\
\text { recurrence }\end{array}$ \\
\hline $\begin{array}{l}\text { Langerhan's } \\
\text { histiocytosis }\end{array}$ & $\begin{array}{l}\text { Age: wide range, } \\
50 \%<10 \text { years } \\
\text { old } \\
\text { Site: virtually any } \\
\text { bone; jaws affected } \\
\text { in } 10-20 \% \\
\text { Behavior: loose } \\
\text { teeth, mucosal or } \\
\text { skin granulomas }\end{array}$ & $\begin{array}{l}\text { "Punched out" } \\
\text { radiolucencies w/o } \\
\text { corticated rim; } \\
\text { occasionally ill- } \\
\text { defined } \\
\text { radiolucency; } \\
\text { "scooped out" } \\
\text { alveolar bone, teeth } \\
\text { "floating in air" }\end{array}$ & $\begin{array}{l}\text { Inflammatory cells, } \\
\text { mainly eosinophils; } \\
\text { giant cells and } \\
\text { necrosis; Birbeck } \\
\text { granules on electron } \\
\text { microscopy }\end{array}$ & $\begin{array}{l}\text { CD1a, } \\
\text { S-100 }\end{array}$ & $\begin{array}{l}\text { Curettage, resection, } \\
\text { radiotherapy, } \\
\text { chemotherapy, } \\
\text { intra-lesional } \\
\text { steroids, systemic } \\
\text { steroids }\end{array}$ & $\begin{array}{l}\text { Rare } \\
\text { recurrence }\end{array}$ \\
\hline $\begin{array}{l}\text { Rosai-Dorfman } \\
\text { disease }\end{array}$ & $\begin{array}{l}\text { Age: wide range, } \\
\text { usually children } \\
\text { and young adults } \\
\text { Site: lymph nodes } \\
\text { Behavior: enlarged } \\
\text { lymph nodes, } \\
\text { painless }\end{array}$ & $\begin{array}{l}\text { Enlarged lymph } \\
\text { nodes }\end{array}$ & $\begin{array}{l}\text { Pericapsular fibrosis } \\
\text { and dilated sinuses, } \\
\text { heavily infiltrated } \\
\text { with large foamy } \\
\text { histiocytes } \\
\text { engulfing } \\
\text { lymphocytes, and } \\
\text { plasma cells }\end{array}$ & $\begin{array}{l}\text { CD68, } \\
\text { S-100 }\end{array}$ & $\begin{array}{l}\text { Surgical debulking, } \\
\text { clinical } \\
\text { observation, } \\
\text { systemic steroids }\end{array}$ & Can recur \\
\hline $\begin{array}{l}\text { Erdheim-Chester } \\
\text { disease }\end{array}$ & $\begin{array}{l}\text { Age: wide range, } \\
\text { mostly } 5 \text { th-7th } \\
\text { decades } \\
\text { Site: bone and } \\
\text { multiple organs } \\
\text { Behavior: bone pain } \\
\text { at knees and ankles }\end{array}$ & $\begin{array}{l}\text { Bilateral cortical } \\
\text { sclerosis involving } \\
\text { the diametaphyseal } \\
\text { regions of long } \\
\text { bones }\end{array}$ & $\begin{array}{l}\text { Lipid-laden } \\
\text { histiocytes with } \\
\text { foamy and } \\
\text { eosinophilic } \\
\text { cytoplasm, fibrosis }\end{array}$ & CD68 & $\begin{array}{l}\text { Interferon- } \alpha \\
\text { Peginterferon- } \alpha 2 \mathrm{a} \\
\text { Cladribine } \\
\text { Anakinra } \\
\text { Vemurafenib }\end{array}$ & $\begin{array}{l}\text { 1- and 5-year } \\
\text { survival } \\
\text { rates } 96 \text { and } \\
68 \% \\
\text { respectively }\end{array}$ \\
\hline $\begin{array}{l}\text { Non-ossifying } \\
\text { fibroma }\end{array}$ & $\begin{array}{l}\text { Age: highest } \\
\text { incidence in long } \\
\text { Bones between } 4 \text { and } \\
8 \text { years old } \\
\text { Gnathic lesions } \\
\text { usually identified } \\
\text { on average } \\
20 \text { years old } \\
\text { Site: long bones } \\
\text { Behavior: } \\
\text { asymptomatic, } \\
\text { expansile }\end{array}$ & $\begin{array}{l}\text { Mutlilocular } \\
\text { radiolucency, } \\
\text { expansile, thinning } \\
\text { of cortices }\end{array}$ & $\begin{array}{l}\text { Foam cells with faint } \\
\text { granular cytoplasm } \\
\text { and small round } \\
\text { nulcei, spindle-cells } \\
\text { fibrous tissue in a } \\
\text { storiform pattern, } \\
\text { giant } \\
\text { multinucleated } \\
\text { cells, hemosiderin }\end{array}$ & CD68 & Observation & $\begin{array}{l}\text { Good, } \\
\text { spontaneous } \\
\text { regression }\end{array}$ \\
\hline $\begin{array}{l}\text { Benign fibrous } \\
\text { histicytoma }\end{array}$ & $\begin{array}{l}\text { Age: wide range, } \\
60 \% \text { of cases } \\
>20 \text { years old } \\
\text { Site: femur, tibia, } \\
\text { pelvis } \\
\text { Behavior: pain, } \\
\text { pathological } \\
\text { fracture }\end{array}$ & $\begin{array}{l}\text { Radiolucency } \\
\text { w/irregular sclerotic } \\
\text { margins and } \\
\text { expansion, thin } \\
\text { cortices, internal } \\
\text { trabeculation or } \\
\text { pseudoseptations, } \\
\text { may be evident }\end{array}$ & $\begin{array}{l}\text { Foam cells with faint } \\
\text { granular cytoplasm } \\
\text { and small round } \\
\text { nuclei, spindle-cells } \\
\text { fibrous tissue in a } \\
\text { storiform pattern, } \\
\text { giant } \\
\text { multinucleated } \\
\text { cells, hemosiderin }\end{array}$ & CD68 & Curettage, resection & Good \\
\hline
\end{tabular}


Table 1 continued

\begin{tabular}{|c|c|c|c|c|c|c|}
\hline Lesion & Clinical features & Radiographic features & $\begin{array}{l}\text { Histopathologic } \\
\text { features }\end{array}$ & $\begin{array}{l}\text { Positive } \\
\text { markers }\end{array}$ & Treatment & Prognosis \\
\hline Gaucher's disease & $\begin{array}{l}\text { Age: } \\
\text { Site: long bones, } \\
\text { mandible } \\
\text { Behavior: systemic } \\
\text { pathologies; } \\
\text { when a/w jaw lesion } \\
\text { may delayed } \\
\text { eruption of } \\
\text { permanent teeth, } \\
\text { yellow } \\
\text { pigmentation of } \\
\text { mucosa, } \\
\text { hyposalivation, } \\
\text { dental pain and } \\
\text { mobility, sinusitis, } \\
\text { and osteomyelitis; } \\
\text { usually } \\
\text { asymptomatic }\end{array}$ & $\begin{array}{l}\text { Pseudocystic (soap- } \\
\text { bubble) } \\
\text { well-defined } \\
\text { radiolucent lesions } \\
\text { in premolar-molar } \\
\text { regions; rarefication } \\
\text { of trabeculations, } \\
\text { increased bone } \\
\text { marrow spaces } \\
\text { w/scalloping and } \\
\text { loss of lamina dura } \\
\text { of affected teeth } \\
\text { (generalized } \\
\text { osteopenia); } \\
\text { expansion, cortical } \\
\text { perforation, root } \\
\text { resorption }\end{array}$ & $\begin{array}{l}\text { Lipid-laden } \\
\text { macrophages } \\
\text { infiltrating } \\
\text { connective tissue; } \\
\text { characteristic } \\
\text { Gaucher's cells } \\
\text { (enlarged granular } \\
\text { cytoplasm and } \\
\text { round displaced } \\
\text { nuclei) }\end{array}$ & & $\begin{array}{l}\text { Biopsy if needed for } \\
\text { definitive } \\
\text { diagnosis; enzyme } \\
\text { replacement } \\
\text { therapy (ERT; } \\
\text { glucocerebrosidase) }\end{array}$ & $\begin{array}{l}\text { Guarded } \\
\text { (depending } \\
\text { on access to } \\
\text { ERT) }\end{array}$ \\
\hline $\begin{array}{l}\text { Systemic diseases } \\
\text { (hyperlipidemia } \\
\text { type II and III, } \\
\text { diabetes } \\
\text { mellitus) }\end{array}$ & $\begin{array}{l}\text { Age: } 3 \text { rd-4th } \\
\text { decades } \\
\text { Site: subcutaneous } \\
\text { and tendon } \\
\text { xanthomas, } \\
\text { xanthelasma, and } \\
\text { corneal arcus; bony } \\
\text { manifestation } \\
\text { uncommon } \\
\text { Behavior: } \\
\text { presentation } \\
\text { depends on lesion } \\
\text { location and extent } \\
\text { (may include } \\
\text { headache, tinnitus, } \\
\text { cranial nerve } \\
\text { palsies, and other } \\
\text { neurological } \\
\text { manifestations } \\
\text { when found } \\
\text { intracranially) }\end{array}$ & $\begin{array}{l}\text { Generalized } \\
\text { osteopenia, } \\
\text { loculated lytic } \\
\text { lesion, osseous } \\
\text { remodeling }\end{array}$ & $\begin{array}{l}\text { Foamy macrophages, } \\
\text { cholesterol crystal } \\
\text { clefts, inflammatory } \\
\text { reaction with giant } \\
\text { cells and resultant } \\
\text { fibrosis }\end{array}$ & & $\begin{array}{l}\text { Lipid lowering } \\
\text { agents } \\
\text { Hypoglycemic agents } \\
\text { Surgical debulking } \\
\text { may be necessary } \\
\text { to alleviate } \\
\text { neurological } \\
\text { symptoms }\end{array}$ & $\begin{array}{l}\text { Good-Garded } \\
\text { (depending } \\
\text { on location } \\
\text { and response } \\
\text { to medical } \\
\text { therapy) }\end{array}$ \\
\hline
\end{tabular}

appearance with small ill-defined radiolucencies and areas of increased density [3, 4, 12]. Calcifications have been reported in the osteolytic areas [1, 13]. The lesion can expand the cortices, as in the reported case, and when lytic it may mimic a malignant process [9, 14]. Computed tomogram shows loss of normal trabecular pattern in the medullary cavity, and the lesion may have a higher density than the normal bone marrow [14]. Magnetic resonance imaging has been used and shows mixed hypointensityhyperintensity on both T1 and T2 weighted MRI [2, 13].

Histopathologically, histiocytes and lipid-containing macrophages, or foam cells, are present exhibiting a faintly granular cytoplasm, occasional multinucleated giant cells, and fibrous connective tissue. Cholesterol clefts can also be present. Immunohistochemical staining is used to differentiate the macrophage, or non-Langerhans histiocytic process, from the Langerhan's histiocytosis. Xanthomas exhibit diffuse strong positive staining for CD 68 and are uniformly negative for S-100 and CD1a, in contrast to Langerhan's cell histiocytosis, which is positive for S-100 and CD1a $[4,5]$.

Additional bone lesions that display xanthomatous presentations should be considered on histological differential diagnosis, such as the non-ossifying fibroma (NOF) and benign fibrous histiocytoma (BFH). Histologically, the two lesions are indifferentiable. The diagnosis is made 
according to clinical and radiological appearance [15]. NOF usually affects the long bones [16, 17]. Histopathologically, the NOF and BFH shows spindle-shaped cells, foamy histiocytes, and multi-nucleated giant cells with a stromal tissue background in a storiform pattern, differentiating the two from the xanthoma [18]. NOF and BFH also show positive staining with CD68 $[19,20]$.

Other disease processes that display xanthomatous presentations include Rosai-Dorfman disease, ErdheimChester disease, and Gaucher's disease. Rosai-Dorfman disease involves lymph nodes throughout the body and has positive staining for both S-100 and CD 68 [21]. ErdheimChester disease stains positive for CD 68 and negative for CD1a and S-100, like the osseous xanthoma. Clinically, it presents bilaterally and symmetrically in long bones. Gaucher's disease, the most common lysosomal storage disease, can also affect the gnathic bones [22]. In Gaucher's disease, a genetic mutation causes lipids to accumulate in different organs, including bones. The histopathologic exam demonstrates vacuolated lipid-laden reticuloendothelial cells (Gaucher's cells) infiltrating the connective tissue with enlarged granular cytoplasm and round displaced nuclei [22]. Furthermore, systemic metabolic and lipid diseases (i.e. type II and III hyperlipidemia and diabetes mellitus) should be included for completion of the differential diagnosis [5]. Table 1 lists the different clinical, radiological and histological findings of these different entities.

Controversy exists whether the xanthoma is a reactive process of a benign neoplastic process. Daley et al. [16] discuss this controvery in detail, but conclude that it is a unique histopathologic entity. Different theories regarding the pathogenesis of xanthoma exist. One theory suggests lipid leakage from vessels after local trauma or hemorrhage. Lipids accumulate within macrophages, causing what are histologically noted as foam cells, and extracellular cholesterol crystallizes into clefts. The cholesterol clefts induce an inflammatory giant cell reaction causing fibrosis [2]. Dahlin [23] proposed that the lesion is secondary to a pre-existing process such as fibrous dysplasia, aneurysmal bone cyst, idiopathic bone cavity, giant cell tumors, or brown tumor of hyperparathyroidism. Another theory suggests xanthomatous transformation of undifferentiated mesenchymal cells by lipotrophic factors in the blood in patients with autoimmune conditions [2].

After histologic diagnosis of intrabony xanthoma is rendered, a lipid metabolic disorder work-up consisting of a full clinical and hematologic exam is necessary to exclude systemic endocrine or metabolic disease. Hematologic exam will consist of a lipid profile, amylase, blood chemistry, and hemoglobin A1c.

When the lesion is secondary to hyperlipidemia, the patient should undergo dietary restriction. Medications are suggested if dietary control fails. The lesion may disappear after treating the hyperlipidemia. The long term prognosis is good, and malignant transformation has not been reported [24].

Primary intraosseous xanthoma of the mandible can be treated with curettage, and the prognosis is satisfactory even with only partial excision [2, 3, 24]. When removed entirely by curettage, recurrence has not been reported [16]. Complete intra-lesional curettage of the xanthoma with bone grafting (particulate allograft) is recommended in the orthopedic literature for bones prone to pathologic fracture, such as the pelvis and tibia, with internal fixation or protection from full weightbearing [11]. When complete curettage is impractical, such as the spine or cranial base, subtotal curettage has been suggested [24]. In the mandible, spontaneous resolution has not been reported [16]. Radical excision and chemotherapy are discouraged and radiation therapy may have limited therapeutic effect as the xanthoma may not be a true neoplastic disorder [24].

\section{References}

1. Huang GS, Huang CW, Lee CW, et al. Xanthoma of the sacrum. Skeletal Radiol. 2004;33:674-8.

2. Muthusamy KA, Azmi K, Narayanan P, et al. Bilateral temporal bone xanthoma: case report. J Neurosurg. 2008;108:361-4.

3. Marqués Mateo M, Puche Torres M, Miragall Alba L, et al. Primary mandibular bone xanthoma: a case report. Int $\mathrm{J}$ Oral Maxillofac Surg. 2004;33:86-7.

4. Harsanyi BB, Larsson A. Xanthomatous lesions of the mandible: osseous expression of non-X histiocytosis and benign fibrous histiocytoma. Oral Surg Oral Med Oral Pathol. 1988;65:551-66.

5. de Moraes Ramos-Perez FM, de Pádua JM, Silva-Sousa YTC, et al. Primary xanthoma of the mandible. Dentomaxillofac Radiol. 2011;40:393-6.

6. Bonhomme GR, Loevner LA, Yen DM, Deems DA, Bigelow DC, Mirza N. Extensive intracranial xanthoma associated with type II hyperlipidemia. Am J Neuroradiol. 2000;21:353-5.

7. Bertoni F, Unni KK, McLeod RA, Sim FH. Xanthoma of bone. Am J Clin Pathol. 1988;99:377-84.

8. Mosby EL, Albright JE, Messer EJ, et al. Case 44, part II: xanthoma of the mandible. J Oral Maxillofac Surg. 1983;41:268-70.

9. Inserra S, Einhorn TA, Vigorita VJ, Smith AG. Intraosseous xanthoma associated with hyperlipoproteinemia: a case report. Clin Orthop Relat Res. 1984;187:218-22.

10. Ali S, Fedenko A, Matcuk G, et al. Bilateral primary xanthoma of the humeri with pathologic fractures: a case report. World J Radiol. 2013;5:345-8.

11. Alden KJ, McCarthy EF, Weber KL. Xanthoma of bone: a report of three cases and review of the literature. Iowa Orthop J. 2008;28:58-64.

12. Slootweg PJ, Swart JG, van Kaam N. Xanthomatous lesion of the mandible: report of a case. Int J Oral Maxillofac Surg. 1993;22: 236-7.

13. Yamamoto $\mathrm{T}$, Kawamoto $\mathrm{T}$, Marui $\mathrm{T}$, et al. Multimodality imaging features of primary xanthoma of the calcaneus. Skeletal Radiol. 2003;32:367-70.

14. Fink IJ, Lee MA, Gregg RE. Radiographic and CT appearance of intraosseous xanthoma mimicking a malignant lesion. $\mathrm{Br} \mathrm{J}$ Radiol. 1985;58:262-4. 
15. Kyriakos M. Benign fibrous histiocytoma of bone. In: Fletcher CDM, Unni KK, Mertens F, editors. World health organization classification of tumours. Pathology and genetics of tumours of soft tissue and bone. Lyon: IARC Press; 2002. p. 292-3.

16. Daley T, Dunn G, Darling M. Central xanthoma of the jaws: a clinicopathologic entity? Oral Surg Oral Med Oral Pathol Oral Radiol. 2015;119:92-100.

17. Bowers LM, Cohen DM, Bhattacharyya I, et al. The non-ossifying fibroma: a case report and review of the literature. Head Neck Pathol. 2013;7:203-10.

18. Betsy M, Kupersmith LM, Springfield DS. Metaphyseal fibrous defects. J Am Acad Orthop Surg. 2004;12:89-95.

19. Akbulut S, Zulfu A, Basbug M. Benign fibrous histiocytoma arising from the right shoulder: is immunohistochemical staining always required for a definitive diagnosis? Int Surg Case Rep. 2012;3:287-9.
20. Katagiri W, Nakazawa M, Kishino M. Benign fibrous histiocytoma in the condylar process of the mandible: case report. $\mathrm{Br} \mathrm{J}$ Oral Maxillofac Surg. 2008;46:e1-2.

21. Pradhananga RB, Dangol K, Shrestha A, Baskota DK. Sinus histiocytosis with massive lymphadenopathy (Rosai-Dorfman disease): a case report and literature review. Int Arch Otorhinolaryngol. 2014;18:406-8.

22. Ahmadieh A, Farnad F, Sedghizadeh P. Gaucher disease with jawbone involvement: a case report. J Med Case Rep. 2014;8: 360.

23. Dahlin DC. Bone tumors. 2nd ed. Springfield: Charles C Thomas; 1967. p. 97.

24. Huang CF, Cheng SN, Hung CH, et al. Xanthoma of bone in the normolipidic child: report of one case. Acta Paediatr Taiwan. 2000;41:158-60. 